\title{
FINAL REPORT ON THE REMEDIAL ACTION AT THE ACID/PUEBLO CANYON SITE Los Alamos, New Mexico
}

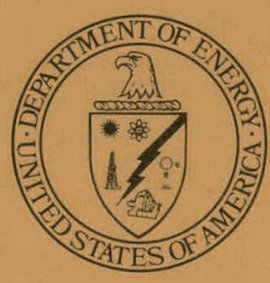

Technical Information Center

Office of Scientific and Technical Information 


\section{DISCLAIMER}

This report was prepared as an account of work sponsored by an agency of the United States Government. Neither the United States Government nor any agency Thereof, nor any of their employees, makes any warranty, express or implied, or assumes any legal liability or responsibility for the accuracy, completeness, or usefulness of any information, apparatus, product, or process disclosed, or represents that its use would not infringe privately owned rights. Reference herein to any specific commercial product, process, or service by trade name, trademark, manufacturer, or otherwise does not necessarily constitute or imply its endorsement, recommendation, or favoring by the United States Government or any agency thereof. The views and opinions of authors expressed herein do not necessarily state or reflect those of the United States Government or any agency thereof. 


\section{DISCLAIMER}

Portions of this document may be illegible in electronic image products. Images are produced from the best available original document. 


\section{DISCLAIMER}

This report was prepared as an account of work sponsored by an agency of the United States Government. Neither the United States Government nor any agency thereof, nor any of their employees, makes any warranty, express or implied, or assumes any legal liahility or responsibility for the accuracy, completeness, or usefulness of any information, apparatus, product, or process disclosed, or represents that its use would not infringe privately owned rights. Reference herein to any specific commercial product, process, or service by trade name, trademark, manufacturer, or otherwise does not necessarily constitute or imply its endorsement, recommendation, or favoring by the United States Government or any agency thereof. The views and opinions of authors expressed herein do not necessarily state or reflect those of the United States Government or any agency thereof.

This report has been reproduced directly from the best available copy.

Available from the National Technical Information Service, U. S. Department of Commerce, Springfield, Virginia 22161.

Price: Printed Copy A03

Microfiche A01

Codes are used for pricing all publications. The code is determined by the number of pages in the publication. Information pertaining to the pricing codes can be found in the current issues of the following publications, which are generally available in most libraries: Energy Reseurch Abstracts (ERA); Government Reports Announcements and Index (GRA and I); Scientific and Technical Abstract Reports (STAR); and publication NTIS-PR-360 available from NTIS at the above address. 
FINAL REPORT ON

REMEDIAL ACTION AT THE ACID/PUEBLO CANYON SI'IE

LOS ALAMOS, NEW MEXICO

OCTOBER 1984

Prepared for

UNITED STATES DEPARTMENT OF ENERGY

ONK RIDGE DPERATTONS OFFICE

Under Contract No. DE-ACO5-81OR20722

By
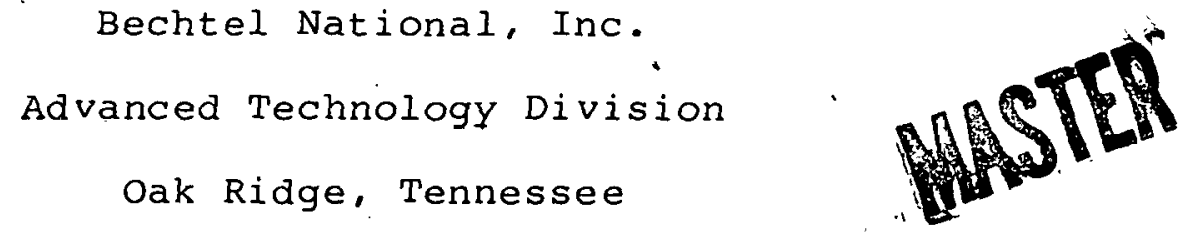

Bechtel Job No. 14501 
THIS PAGE

\section{WAS INTENTIONALLY LEFT BLANK}


The Acid/Pueblo Canyon site (TA-45) was designated in 1976 for remedial action under the Formerly Utilized Sites Remedial Action Program (FUSRAP). During the period 1943-64 untreated and treated liquid wastes generated by nuclear weapons research activities at the Los Alamos Scientific Laboratory (LASL) were discharged into the two canyons. A survey of the site conducted by LASL in 1976-77 identified two areas where radiological contamination exceeded criteria levels. The selected remedial action was based on extensive radiological characterization and comprehensive engineering assessments and comprised the excavation and disposal of $390 \mathrm{yd}^{3}$ of contaminated soil and rock.

This document describes the background to the remedial action, the parties involved in administering and executing it, the chronology of the work, verification of the adequacy of the remedial action, and the cost incurred. 


\section{THIS PAGE}

\section{WAS INTENTIONALLY}

\section{LEFT BLANK}


$\underline{\text { Page }}$

1.0 Introduction

2.0 Site Description and Background

3.0 FUSRAP Organization for the Acid/Pueblo Canyon Remedial Action

3.1 Administrative Organization . 6

3.2 Field Organization 6

4.0. Remedial Action $\quad 8$

4.1 Applicable Criteria 8

4.2. Site Characterization 8

4.3 Preparations for Remedial Action Implementation 11

4.4 Chronology of Remedial Action 14

5.0 Radiological Support $\quad 17$

5.1 Access Control . 17

5.2 Personnel Training 17

5.3 Personnel Monitoring 18

5.3.1 Bioassay. 18

5.3 .2 Dosimetry 18

5.3.3 Lapel Air Gamplers 19

5.4 Environmental Monitoring 19

5.5 In Situ Surveys to Establish. Excavation Limits 19

5.5.1 Near-Surface Gamma Measurements 20

5.5.2 Surface Gamma Measurements 20

5.5.3 Surface Beta-Gamma Measurements 20

5.6 Deterimation of Compliance : $\quad 20$

5.7 Post-Remedial Action Status 22

5.8 Analysis of Remaining Contamination Beyond
the Two Remedial Action Areas

6.0 Cost 


\section{LIST OF FIGURES}

Figure Title

Page

2-1 Location of Acid/Pueblo Canyon Site

4-1 Areas of Residual Radioactivity at Acid Canyon 10

4-2 Pre-Remedial Action Plutonium-239.

Concentration in Soil in $\mathrm{pCi} / \mathrm{g}$

4-3 Map of Upper Acid Canyon Site During

Remedial Action

5-1 Post-Remedial Action Plutonium-239

Concentration in Soil in $\mathrm{pCi} / \mathrm{g}$

\section{LIST OF TABLES}

Table Title

$\underline{\text { Page }}$

4-1 Soil Cleanup Criteria for Remedial

Action at Acid/Pueblo Canyon

4-2 Acid Canyon Pre-Remedial Action Radiological

Survey Data

5-1 Acid Canyon Post-Remedial Action Soil

Sample Data

5-2 Acid Canyon Post-Remedial Action External

Exposure Rates

6-1 Acid/Pueblo Canyon Cost Summary 
ABBREVIATIONS

cm

ft

$f t^{3}$

gal

in.

m

$m^{2}$

$\mu \mathrm{Ci} / \mathrm{CC}$

$\mu \mathrm{R} / \mathrm{h}$

$\mathrm{mR}$

$\mathrm{m} R / \mathrm{h}$

$\mathrm{pCi} / \mathrm{g}$

$\mathrm{pCi} / \mathrm{I}$

$\mathrm{yd}^{3}$ centimeter

foot

cubic foot

gallon

inch

meter

square meter

microcurie per cubic centimeter microroentgen per hour

milliroentgen

milliroentgen per hour

picocurie per gram

picocurie per liter

cubic yard 


\subsection{INTRODUCT ION}

In 1974 the Atomic Energy Commission (AEC) initiated a survey program to identify and radiologically characterize all formerly utilized U.S. Army Corps of Engineers' Manhattan Engineer District (MED) and AEC sites involved with nuclear materials. With the establishment of the Department of Energy (DOE) in 1977, the responsibility for this survey program was assigned to the Assistant Secretary for the Environment (ASEV), who entitled it the Formerly Utilized Sites Remedial Action Program (FUSRAP). Since mid-1979 FUSRAP responsibilities have been shared variously by the ASEV and the Assistant Secretary for Energy Technology [now Assistant Secretary for Nuclear Energy (ASNE)]. Effective in 1982 all major responsibilities (site identification, radiological characterization, determination of the need for remedial action, implementation of the remedial action, including waste disposal or stabilization of residual material, and post remedial action certification) were consolidated and became the responsibility of ASNE.

Following identification of a site and determination of whether DOE has authority to undertake remedial action, radiological survey records are reviewed. If such data are lacking or incomplete, further surveys are conducted as necessary. The FUSRAP Project Management Contractor (PMC) and its subcontractors prepare a series of engineering studies and environmental reports for the site to evaluate remedial action alternatives. Documentation required by the National Environmental Policy Act (NEPA) as part of this evaluation is prepared by the Argonne National Laboratory (ANL). The action that is deemed appropriate by DOE based on the NEPA proccss evaluations is then implemented with consideration for public safety and in compliance with the Atomic Energy Act of 1954 , as amended, and related Nuclear Regulatory Comission (NRC) or applicable federal, state, and local licensing requirements. 
Remedial action at the Acid/Pueblo Canyon site was administered by DOE through its FUSRAP Lead Field office, the Oak Ridge Operations (ORO) Office and FUSRAP PMC, Bechtel National, Inc. (BNI). The Los Alamos National (formerly Scientific) Laboratory (LANL) and DOE Los Alamos Area office (LAAO) provided support to DOE-ORO and BNI. 


\subsection{SITE DESCRIPTION AND BACKGROUND}

Acid and Pueblo Canyons are among numerous canyons cut into the Pajarito Plateau in northcentral New Mexico, approximately $100 \mathrm{~km}$ $(60 \mathrm{mi})$ north-northeast of Albuquerque and $40 \mathrm{~km}(25 \mathrm{mi})$ northwest of Santa Fe. Acid Canyon is a small tributary near the head of Pueblo Canyon; it and Middle Pueblo Canyon lie within the townsite of Los Alamos (Figure 2-1). The remedial action site $(T A-45)$ is accessible from Canyon Road, which runs just south of the former TA-45 Waste Treatment Plant as shown on Figure 2-1.

Presently both canyons are used for recreational activities. However, future residential and associated light commercial development is concejvable.

The site was designated a former MED/AEC site because untreated and treated liquid wastes generated by nuclear weapons research activities at the LANL during the period 1943-64 were discharged into the two canyons. From late 1943 until 1951 untreated liquid wastes were discharged. The effluents contained isotopes of strontium, cesium, uranium, plutonium, americium, and tritium. In 1951 a waste treatment plant (TA-45) at Acid Canyon became operational, discharging treated wastes into the canyon until 1964 at which time all wastes were diverted to a new plant (TA-50) located south of Los Alamos Canyon within the present LANL site.

The AEC began decontamination and decommissioning of the TA-45 plant and its associated vehicle decontamination facility in late 1966. Both facilities were demolished and the contaminated building materials, sewer pipe, and soil from the vehicle decontamination facility disposed of at the LASL radioactive waste disposal areas. Portions of the Acid Canyon cliff face were also decontaminated and some contaminated rock, soil, and sediment removed from the canyon floor. By July 1967 the areas around the TA-45 plant and in Acid Canyon were considered sufficiently free of contamination to permit release from federal government control (Reference 1 ). 


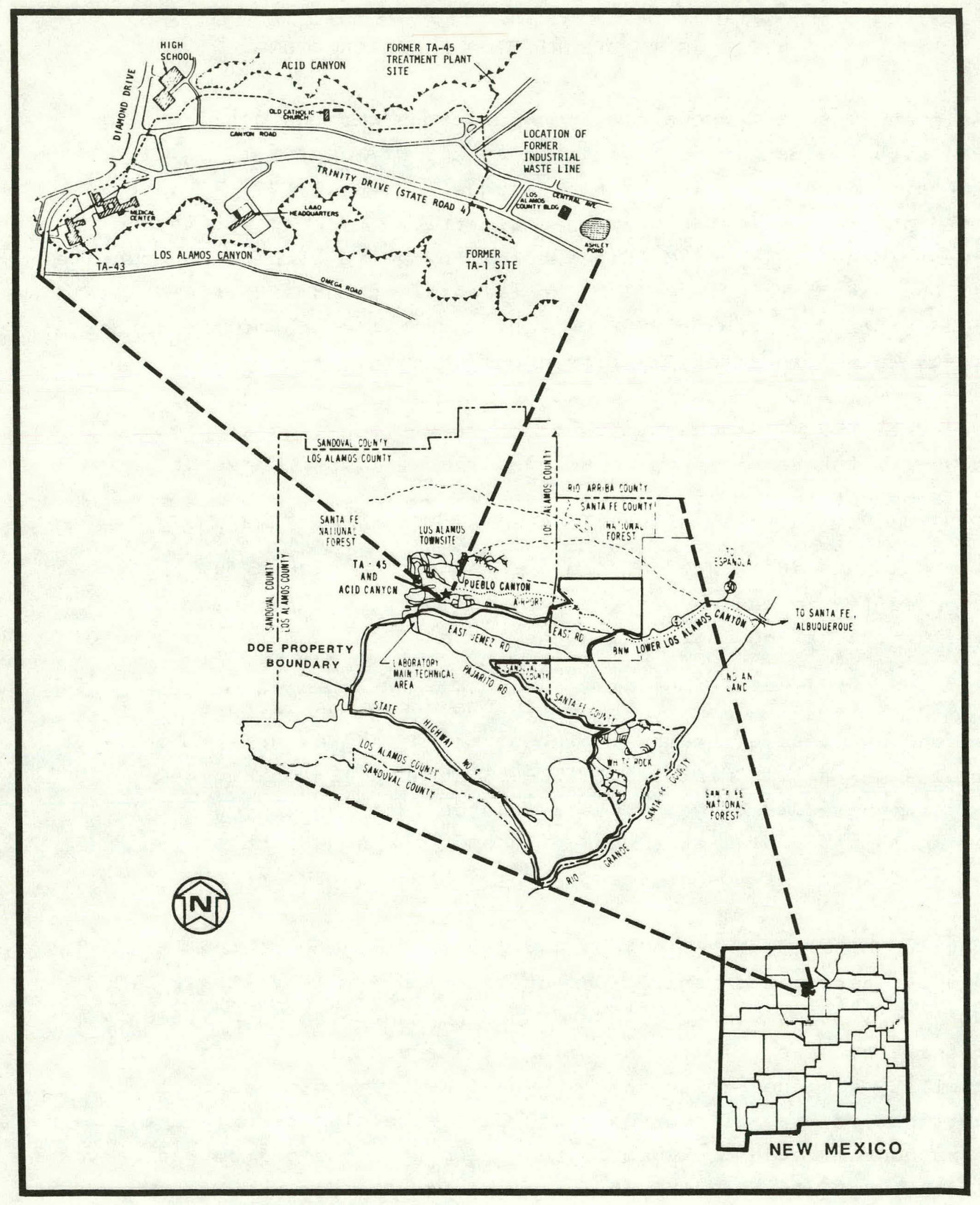

FIGURE 2-1 LOCATION OF ACID/PUEBLO CANYON SITE 
On July 1, 1967 the AEC transferred to the County of Los Alamos ownership of the former TA-45 site, Acid Canyon, and the portion of Pueblo Canyon encompassing the channel from Acid Canyon eastward to a point approximately $1,190 \mathrm{~m}(3,900 \mathrm{ft})$ west of the Los Alamos-Santa Fe county line. The transfer was in accordance with the provisions of the Community Disposal Act, subject to the reservation of an easement for continued access to and maintenance of sampling locations and test wells in and adjacent to the channel in Acid and Pueblo Canyons.

Low-level residual contamination in the channels was monitored periodically as part of routine environmental surveillance conducted by LASL. In 1976 the Acid/Pueblo Canyon site was identified as warranting reevaluation with modern instrumentation and analytical methods to determine whether further corrective measures were required. LANL undertook the resurvey in 1976-77; its final report was issued in 1981 (Reference 1). This and a supplemental survey conducted in 1980 by Ford, Bacon and Davis, Utah (FBDU) indicated that contamination in the areas of the former untreated waste effluent outfall and former vehicle decontamination facility exceeded the cleanup criteria levels specified in subsection 4.1 of this document.

$B N I$ performed an engineering evaluation of the site based on the LANL and FBDU data. In this study BNI presented three remedial action scenarios: no action, minimal action, and decontamination and disposal (Reference 2). LANL prepared the associated environmental analysis report (Reference 3) and ANL prepared the required NEPA analysis documentation (Reference 4). Decontamination and restoration was approved by DOE; BNI, as FUSRAP PMC, was assigned the responsibility for implementation. 


\subsection{ADMINISTRATIVE ORGANIZATION}

Remedial action at the Acid/Pueblo Canyon site was administered by the Technical Services Division of DOE-ORO. BNI, as FUSRAP PMC, planned, managed, and implemented the work for DOE-ORO, beginning in early 1981.

BNI selected Professional Land Surveying (PLS) of Santa Fe, NM, and the Zia Company of Los Alamos, New Mexico to implement the remedial action. BNI was also responsible for radiological monitoring of site personnel and activities. Monitoring was performed by its radiological support subcontractor, Eberline Instrument Corporation (EIC) of Albuquerque, New Mexico. EIC supports BNI in this role at a.l FUSRAP sites.

Argonne National Laboratory (ANL) is the contractor responsible to DOE-ORO for the NEPA process for all FUSRAP sites, including the Acid/Pueblo Canyon site.

The DOE-LAAO facilitated contacts among BNI, LANL, the 7ia rompany, local officials, and the media during preparation for and conduct of remedial action. LANL supplied EIC with protective clothing required in the conduct of the health physics prograll (dust masks, shoe covers, gloves, etc.); members of its Environmental

Surveillance Group conferred with and advised BNI, EIC, PLS, and Zia during remedial action and provided oversight support. Use of the LANL Radioactive Waste Disposal Area G (TA-54) was arranged between DOE-ORO and LANL, using zia for transportation of the wastes.

\subsection{FIELD ORGANIZA'TION}

The site organization consisted of a BNI Site Superintendent who directed the activities of site representatives from PLS (civil survey), the Zia Company (excavation and transportation services), 
and EIC (radiological control and health physics). The BNI site Superintendent also acted as liaison with the representatives of DOE-ORO, DOE-LAAO, and LANL.

The PLS team consisted of a party chief/instrument man and a rodman. The zia Company team consisted of a site engineer and working foremen of the crafts in the work crews (operating engineers, drivers, carpenters, iron workers, and laborers). An average of eight zia personnel worked on the site each day. EIC personnel comprised two health physics technicians. 


\subsection{REMEDIAL ACTION}

\subsection{APPLICABLE CRITERIA}

Remedial action criteria applicable to the Acid/Pueblo Canyon site were the external exposure rates specified by 40 CFR 192 (Reference 5) and the radionuclide concentrations in soil listed in Table 4-1 (References 2, 7, and 8). The radiation exposure rate criterion was based on the annual limit for population exposures of $170 \mathrm{mR}$. For control purposes, an exposure rate of $0.02 \mathrm{mR} / \mathrm{h}$ ( $20 \mu \mathrm{R} / \mathrm{h}$ ) above background was used. Background exposure rates in the Los Alamos area are 9.4-17.4 $\mu \mathrm{R} / \mathrm{h}$. Soil criteria for two separate pathways, food cultivation/ingestion and resuspension/inhalation, were considered. The former is the more restrictive pathway and provides the most conservative criteria against which to evaluate the adequacy of remedial action. However, the latter was the more realistic basis for evaluation in the case of Acid/Pueblo Canyon since the terrain on and near the remedial action site is unsuitable for cultivation.

\subsection{SITE CHARACTERIZATION}

The areas in Acid Canyon requiring remedial action were defined by the radlological survey conducted by LANL in 1976-77. LANL reviewed records of the treatment plant and data on types and amounts of contaminants discharged, environmental monitoring and hydrogeologic studies, and special radioecology research studies. These data were compiled to provide points of comparison and a basis for planning the acquisition of new data, most of which consisted of multiple analyses of several hundred sediment and soil samples for the radionuclides 1 isted in Table 4-1. Additional data on concentrations of these contaminants in air were obtained and gamma surveys performed.

As shown in Figure 4-1, four areas were contaminated in excess of background concentrations. However, only the two designated as having elevated surface activity were contaminated in excess of the 
TABLE 4-1

SOIL CLEANUP CRITERIA FOR REMEDIAL ACTION

AT ACID/PUEBLO CANYON*

\section{Criteria ( $\mathrm{pCi} / \mathrm{g}$ )}

\begin{tabular}{lcc} 
Radionuclide & $\begin{array}{c}\text { Food Cultivation/ } \\
\text { Ingestion }\end{array}$ & $\begin{array}{c}\text { Resuspension/ } \\
\text { Inhalation }\end{array}$ \\
\cline { 2 - 3 } Strontium-90 & 100 & $2 \times 10^{6}$ \\
Cesium-137 & 80 & $7 \times 10^{6}$ \\
Plutonium-238 & 100 & 7600 \\
Plutonium-239 & 100 & 7600 \\
Americium-241 & 20 & --- \\
Uranium (natural) & $40 * *$ & 2200 \\
Radium-226 & $5 * *$ & 7000
\end{tabular}

* Criteria are applied as average concentration per $100 \mathrm{~m}^{2}$ areas.

**After extensive health effects studies, the limit for uranium (natural) was increased to $75 \mathrm{pCi} / \mathrm{g}$ in November 1983 (Reference 9). Based on these and other studies, the limit for radium-226 was also modified in November 1983 to provide for $5 \mathrm{pci} / \mathrm{g}$ in the first $15-\mathrm{cm}$ soil 1 ayer and $15 \mathrm{pCi} / \mathrm{g}$ in successively deeper $15-\mathrm{cm}$ layers (Reference 9). 


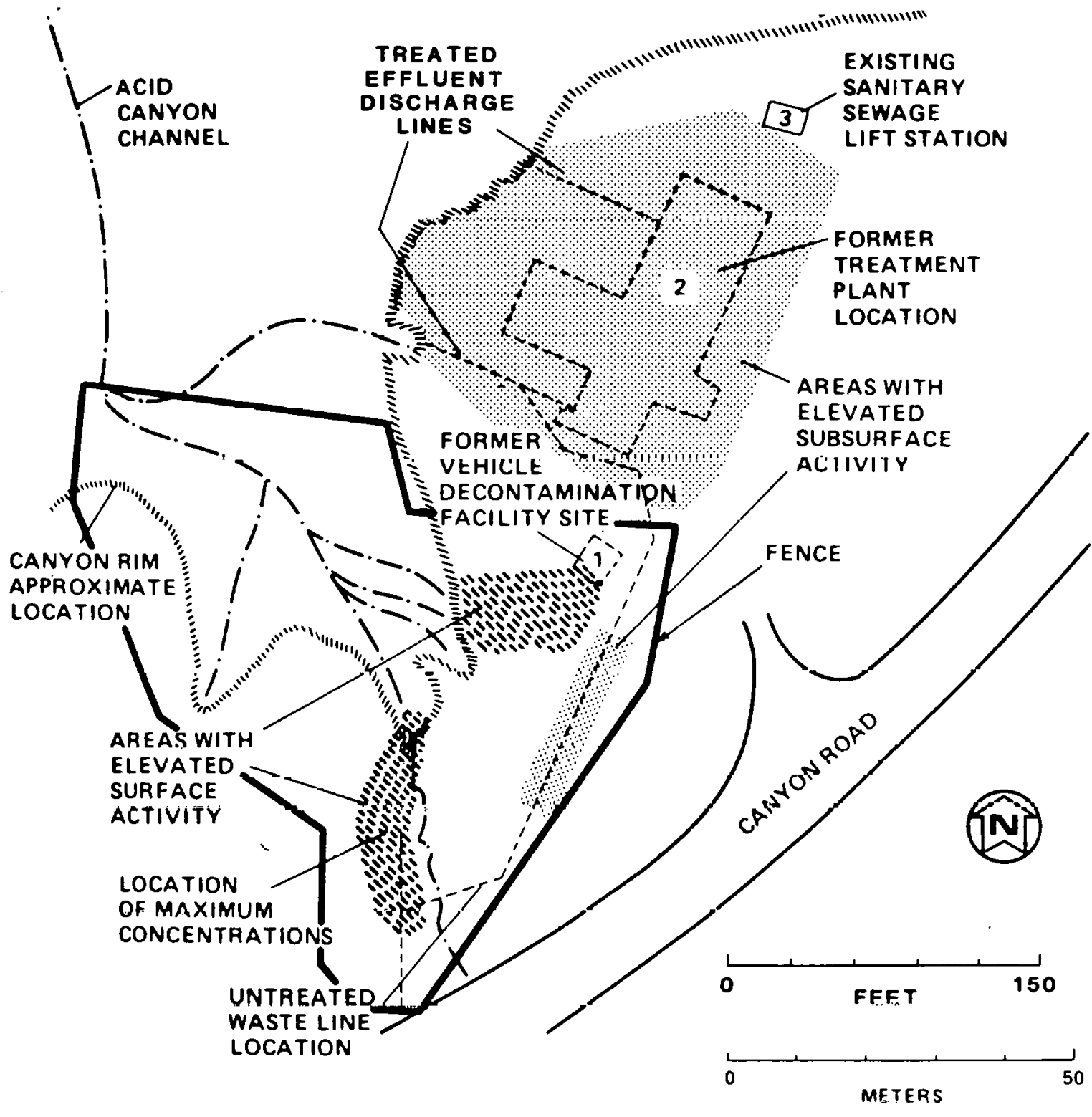

ADAPTED FROM LA-9409-MS

\section{FIGURE 4-1 AREAS OF RESIDUAL RADIOACTIVITY} AT ACID CANYON 
criteria presented in Table 4-1. The LANL radiological survey data for these two areas are presented in Table 4-2 and Figure 4-2. The placement of individual data points was accomplished by extrapolating from small ungridded LANL drawings; therefore, accuracy of placement on Figure 4-2 is $\pm 1.5 \mathrm{~m}$ (5 ft).

Soil sampling was undertaken in 1980 by FBDU to supplement the LASL data and to verify expected background radionuclide concentrations in the Acid Canyon area. Results confirmed the LASL designation of remedial action areas.

\subsection{PREPARATIONS FOR REMEDIAL ACTION IMPLEMENTATION}

The decontamination and restoration scenario approved by DOE specified that the location of the two general areas requiring decontamination would be reestablished using coordinates from previous LASL surveys, a section of the chain-link fence enclosing upper Acid Canyon would be removed to permit access for remedial action, a barrier would be erected across the upper canyon to prevent loss of excavated material, and 30 to $45 \mathrm{~cm}$ ( 12 to 18 in.) of soil and volcanic tuff would be removed and disposed of at the LANL Radioactive Waste Disposal Area G (TA-54). Field measurements made before and during excavation would determine whether further excavation was required to meet criteria levels. The excavated and disturbed areas would be left to stabilize and revegetate naturally.

BNI engineers prepared drawings, specifications, and other subcontract documents preparatory to the issuance of civil survey and excavation subcontracts. A civil survey subcontract package was issued for bids on June 17, 1982. Bids were solicited from firms local to Los Alamos. Three bids were received and evaluated; the subcontract was awarded to PLS on July $28,1982$. 
TABLE 4-2

ACID CANYON PRE-REMEDIAL ACTION

RADIOLOGICAL SURVEY DATA

COORDINATES $^{(1)}$

$\mathrm{pCi} / \mathrm{g}$

\begin{tabular}{|c|c|c|c|c|c|c|}
\hline$\underline{x}$ & $\mathrm{Y}$ & $\begin{array}{c}\text { Plutonium } \\
239 \\
\end{array}$ & $\begin{array}{c}\text { PIutonium } \\
238 \\
\end{array}$ & $\begin{array}{c}\text { Americium } \\
241 \\
\end{array}$ & $\begin{array}{c}\text { Cesium } \\
\quad 137 \\
\end{array}$ & $\begin{array}{c}\text { st rontium } \\
\frac{90}{}\end{array}$ \\
\hline 2.5 & 3.5 & $38 . n$ & ก. 3 & $N / A$ & 78.0 & 183.0 \\
\hline 27 & 17 & 0.6 & 0.0 & $\mathrm{~N} / \mathrm{A}$ & 1.8 & 1.5 \\
\hline 30 & 10 & 34.0 & 0.3 & $N / A$ & 0.3 & 0.6 \\
\hline 30 & 30 & 42.0 & 0.3 & $\mathrm{~N} / \mathrm{A}$ & 176.0 & 229.0 \\
\hline 35 & $30(2)$ & 5.8 & 0.3 & 4.0 & 2.9 & $\mathrm{~N} / \mathrm{A}$ \\
\hline 45 & $60(2)$ & 0.5 & 0.1 & 3.0 & 39.0 & $\mathrm{~N} / \mathrm{A}$ \\
\hline 40 & $30(2)$ & 200.0 & 1.8 & 33.0 & 17.0 & $N / \Lambda$ \\
\hline 45 & $80(2)$ & 1.0 & 0.1 & 1.0 & 2.4 & $N / A$ \\
\hline 50 & 0 & 4.0 & 0.1 & $\mathrm{~N} / \mathrm{A}$ & 1.0 & 1.1 \\
\hline 50 & $45(2)$ & 20.0 & 0.2 & 4.0 & 153.0 & N/A \\
\hline 100 & 0 & 0.3 & 0.01 & $\mathrm{~N} / \mathrm{A}$ & 0.3 & 0.4 \\
\hline 133 & 68 & $86,900.0$ & 326.0 & 55.0 & $10 . \%$ & 1.0 \\
\hline 136 & 62 & $163,000.0$ & 696.0 & $1,200.0$ & 1.1 & 0.9 \\
\hline 1.39 & 0 & 0.2 & 0.0 & $\mathrm{~N} / \mathrm{A}$ & 1.8 & 2.6 \\
\hline 139 & 72 & 3690.0 & 26.4 & 106.0 & 36.0 & 5.1 \\
\hline 140 & 65 & 433.0 & 2.7 & 10.0 & 25.1 & 1.8 \\
\hline 141 & 57 & $16,300.0$ & 70.4 & 126.0 & 2.3 & 2.4 \\
\hline 14.7 & 67 & 61.0 & 0.08 & 1.5 & 2.2 & 0.5 \\
\hline 146 & 57 & 64.0 & 0.26 & 0.9 & 1.9 & 0.9 \\
\hline 157 & 0 & 0.2 & 0.01 & $\mathbb{N} / \mathrm{A}$ & U.7 & 0.5 \\
\hline 157 & 48 & 259.0 & 1.1 & $N / A$ & 0.1 & 0.2 \\
\hline 172 & 33 & 44.0 & 0.3 & N/A & 0.3 & 0.5 \\
\hline 187 & 20 & 12.0 & 0.1 & $\mathrm{~N} / \mathrm{A}$ & 2.2 & 2.9 \\
\hline
\end{tabular}

(1) Based on extrapolation of data presented in DOE/EV-0005/30

(2) Data collected by BNI

N/A Not analyzed

Source: LANL (Reference 1) 


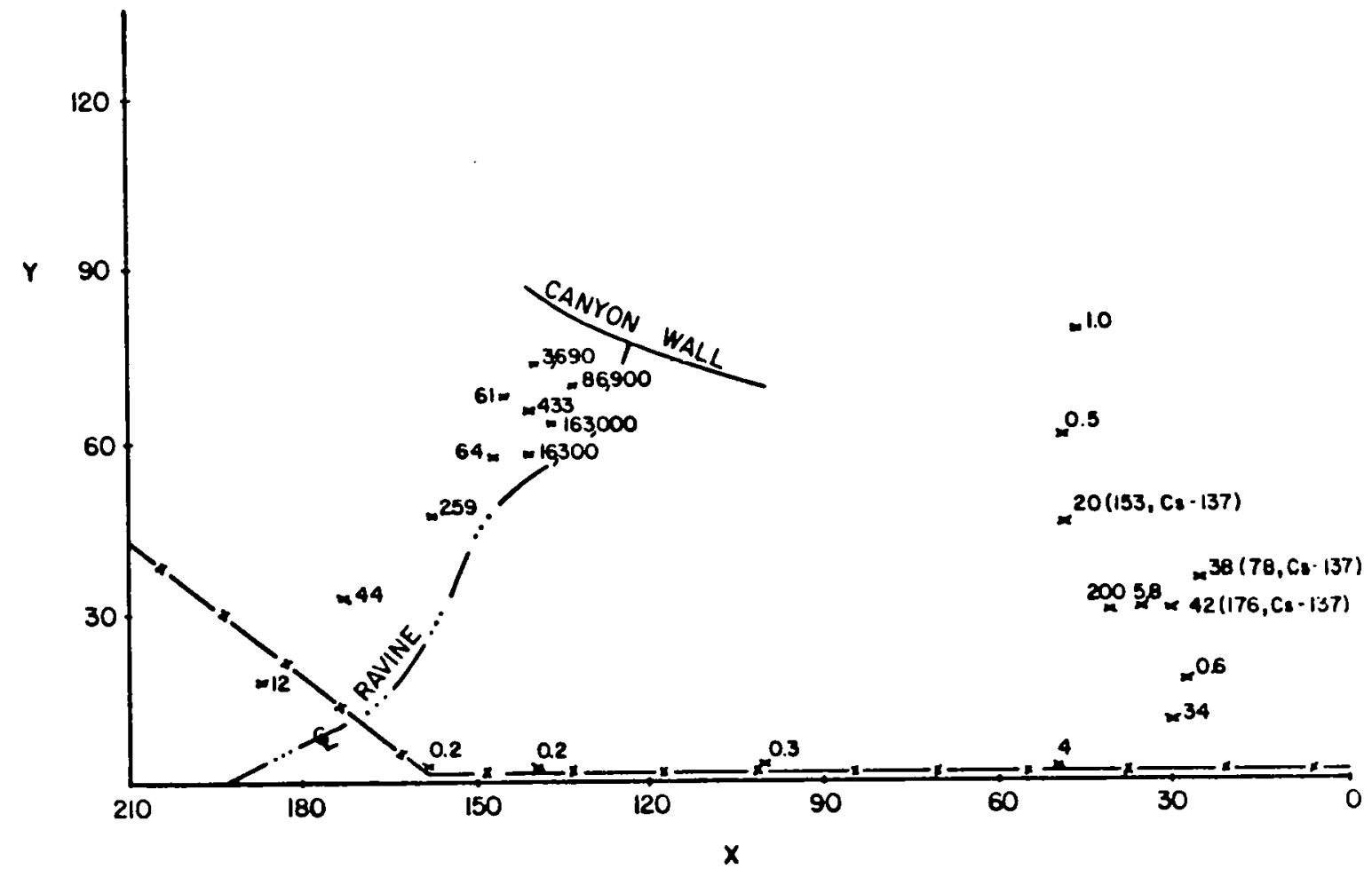

FIGURE 4-2 PRE-REMEDIAL ACTION PLUTONIUM-239 CONCENTRATION IN SOIL IN pCi/g (CESIUM-137 INCLUDED TO INDICATE MIXED FISSION PRODUCT CONTAMINATION) 
A Memorandum Purchase Order for the excavation and transportation of the contaminated material was issued on July 22, 1982 to the $\mathrm{Zia}$ Company. As the prime construction contractor for LAAO, Zia already had the required clearances to operate on the LANL disposal area and experience with radioactive decontamination.

\subsection{CHRONOLOGY OF REMEDIAL ACT ION}

On August 2, 1982 part of the chain-link fence enclosing Acid Canyon was removed to permit access to the remedial action areas, the debris/sediment barrier was installed, and the erection of a vehicle decontamination pad was begun (Figure 4-3). The following day the pad was completed and the site survey grid was tied to the New Mexico state Plane System and the LANL survey grid. PLS established a $4.6 \mathrm{~m} \times 4.6 \mathrm{~m}$ ( $15 \mathrm{ft} \times 15 \mathrm{ft})$ grid over the remedial action area so that pre-remedial action contours could be recorded for subsequent comparison with post-remedial action contours to determine the volume of material removed.

Excavation commenced on August 4 in the area where the untreated effluent discharge line had been located. Contaminated material was excavated in 15 to $20 \mathrm{~cm}$ ( 6 to $8 \mathrm{in.)} 1$ ifts by a backhoe and loaded directly into $18-y d^{3}$ capacity dump trucks lined with reinforced plastic. Excavation was started at the point farthest from the loading point so that contaminated material was not moved over non-contaminated areas. When it was necessary to load over a non-contaminated area, that area was covered with plastic, which was rolled up and disposed of at the end of the operation. A water truck was maintained at the site during excavation so that the excavation area could be wetted to control dust. Hot spot excavation at the former vehicle decontaminations facility was performed manually with spades and shovels. Contaminated earth was loaded into 55-gal drums that were hoisted into dump trucks by an 18-ton hydraulic crane. All contaminated materials were disposed of at the LANL Radioactive Waste Disposal Area G (TA-54). 


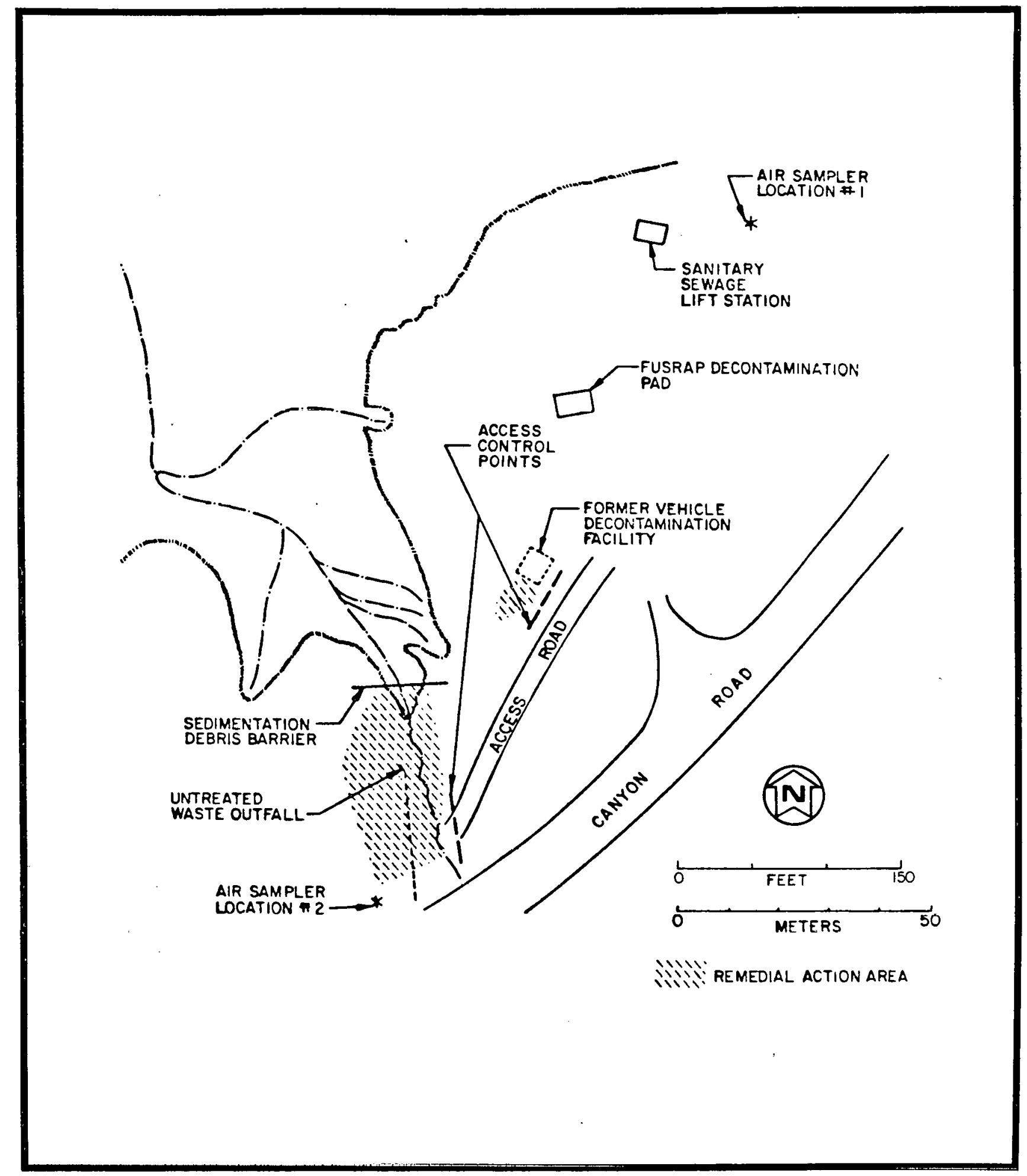

FIGURE 4-3 MAP OF UPPER ACID CANYON SITE DURING REMEDIAL ACTION 
Following excavation EIC took radiological readings and soil samples for laboratory analysis to confirm satisfactory cleanup. While awaiting the results of this analysis, the fence was restored and equipment checked for contamination prior to release from the site. All equipment was found to be non-contaminated. The temporary decontamination pad remained in place; its drainage system was filled in and the debris/sediment barrier was removed from the canyon rim.

Laboratory results indicated that two spots of contamination remained in the untreated waste outfall area. These were excavated and disposed of on August 13 and EIC resurveyed and resampled the areas. The site was closed while awaiting laboratory results of the resampling, although arrangements were made for additional excavation if necessary. Sample analysis indicated that further excavation was required in the untreated waste outfall area. Final excavation was performed from September 27 to september 30, 1982. A total of $390 \mathrm{yd}^{3}$ of contaminated material was excavated in implementing the remedial action.

Backfilling the excavated area was impractical since the material removed was primarily sandstone and tuff. Backfill material placed on the site would have been highly susceptible to erosion.

After excavation activities were completed the site grid was reestablished for the final radiological survey to verify compliance with criteria for unrestricted release. Verification of compliance is discussed in greater detail in subsection 5.6 .

The above work was conducted in accordance with accepted practices and in compliance with the zia Company safety policies, the BNI FUSRAP Health and Safety Program, FUSRAP Radiological Protection Program, and BNI Nuclear Fuels Operation Quality Assurance Prngram as amended for FUSRAP (References 10, 11, and 12). 


\subsection{RADIOLOGICAL SUPPORT}

Support of remedial action by the BNI/EIC health physics staff included access control, personnel training, personnel radiation exposure monitoring, and environmental monitoring. In addition, they established excavation limits in the field following analysis of data from the 1976-77 LANL radiological survey, performed surveys during excavation to determine the effectiveness of the remedial action, and conducted post-remedial action surveys to confirm that decontamination criteria were met.

\subsection{ACCESS CONTROL}

Access to the area was controlled through a point of entry located at the southeast corner of the untreated waste discharge area as shown in Figure 4-3. All personnel entering the controlled area (hatched sections of Figure 4-3) were issued shoe covers and gloves. When activities created a high potential for generating dust all workers were issued dust masks.

When leaving the controlled area all personnel were monitored for contamination. Vehicles were similarly monitored. A decontamination pad wash down area was provided for vehicles. However, during the remedial action activities all vehicles were found to be non-contaminated. Controlled vehicle/material logs were maintained throughout remedial action operations and are now on file at the BNI office in Oak Ridge, Tennessee.

\subsection{PERSONNEL TRAINING}

A radiological safety orientation program was presented to all personnel involved with construction and excavation activities prior to their beginning work. Emphasis was placed on the need for personal protection, contamination control, and monitoring procedures. All training was documented by signed statements from each attendee acknowledging his understanding of the material 
presented. These statements and a list of references and training aids used in the orientation are on file at the BNI Oak Ridge office.

\subsection{PERSONNEL MONITORING}

Radiological monitoring of personnel involved in remedial action was conducted to ensure compliance with protection standards. Personnel were monitored by means of bioassay, dosimetry, and lapel air samplers.

\subsubsection{Bioassay}

Urine specimens were collected from Bechtel and PĹs onsite personnel prior to beginning work and prior to their termination from the job. Specimens were shipped to the EIC Albuquerque laboratory for plutonium-239, cesium-137, and mixed fission products analyses.

Personnel employed by the zia Company were on a bioassay program as part of their routine job functions at Los Alamos and werê, therefore, not included in the FUSRAP bioassay program.

All results from the FUSRAP bioassay program for the remedial action at Acid/Pueblo Canyon were below detectable limits. The detection limit for plutonium-239 is $0.1 \mathrm{pCi} / 1$, for cesium-137 is $30 \mathrm{pCi} / 1$, and for fission products is $15 \mathrm{pCi} / 1$.

\subsubsection{Dosimetry.}

Workers who did not already have an assigned radiation monitoring badge were issued a thermoluminescent dosimeter (TLD) badge. TLD badges were issued prior to the beginning of work and collected upon termination of the job. Results showed that no workers were exposed to gamma radiation levels distingüishable from natural background. All TLD exposure records are on file at the BNI Oak Ridge office. 


\subsubsection{Lapel Air Samplers}

Personnel operating heavy equipment within the remedial action area wore lapel air samplers during all excavation. All results of lapel air samples were less than detectable quantities. Detection limits are less than 25 percent of the applicable concentration guide for controlled areas per DOE Order 5480.1A, Chapter XI (Reference 11).

\subsection{ENVIRONMENTAL MONITORING}

The radiological safety program also provided air quality surveillance. During initial excavation two continuous air samplers were deployed. As shown in Figure 4-3, one was positioned near the access control point to determine pre-excavation radiation levels and one was northeast of the decontamination pad. These samplers were run intermittently for four days. Composite samples of filters for each unit were analyzed for plutonium-238 and -239 , americium-241, cesium-137, strontium-90, and isotopic uranium. All results were less than $1 \times 10^{-13} \mu \mathrm{Ci} / \mathrm{cc}$. During the final excavation only the location near the access control point was monitored. Analysis for gross alpha contamination indicated that all results were less than $1 \times 10^{-13} \mathrm{\mu Ci} / \mathrm{cc}$. These results are less than 10 percent of the most restrictive concentration guides for controlled areas per DOE Order 5480.1A, Chapter XI, $2 \times 10^{-12} \mu \mathrm{Ci} / \mathrm{cc}$ for alpha emitters (plutonium-239) and $1 \times 10^{-9} \mu \mathrm{Ci} / \mathrm{cc}$ for beta emitters (strontium-90).

\subsection{IN SITU SURVEYS TO ESTABLISH EXCAVATION LIMITS}

Excavation limits that had been defined from survey data collected by LANL were verified or modified as required. Survey techniques included surface gamma measurements, near-surface gamma measurements, and surface beta-gamma measurements as described below. The same techniques were used to detect hot spots and to determine post-remedial action compliance with release criteria. 


\subsubsection{Near-Surface Gamma Measurements}

Near-surface gamma measurements were made on a $1.5-\mathrm{m} \times 1.5-\mathrm{m}$ ( $5-\mathrm{ft} \mathrm{x}$ 5-ft) grid using a $5 \mathrm{~cm}$ x $5 \mathrm{~cm}$ detector (Eberline Model SPA-3) coupled to a rate meter/scaler (Eberline Model PRS-1). Measurements were made at a height of $1 \mathrm{~m}$ ( $3 \mathrm{ft}$ ) above the ground surface. The system was calibrated in $\mu \mathrm{R} / \mathrm{h}$.

\subsubsection{Surface Gamma Measurements}

Surface gamma measurements were made on a $1.5-\mathrm{m} \times 1.5-\mathrm{m}$ (5-ft $\times$ 5-ft) grid using a $5 \mathrm{~cm} \times 0.2 \mathrm{~cm}$ NaI detector (Eberline Model PG-2) coupled to a rate meter/scaler (Eberline Model PRS-1). Measurements with the PG-2 were made at approximately $2-3 \mathrm{~cm}$ ( 1 in.) above the ground surface.

\subsubsection{Surface Beta-Gamma Measurements}

Surface beta-gamma measurements were made on a $1.5-m \times 1.5-m$ (5-ft $x$ 5-ft) grid using a pancake geometry Geiger Mueller probe (Eberline Model HP-210) coupled to a rate meter/scaler (Eberline Model PRS-l). Measurements using the HP-210 were made approximately $1 \mathrm{~cm}(0.5 \mathrm{in.})$ above the ground surface.

\subsection{DETERMINATION OF COMPLIANCE}

Following excavation soil samples were collected on a $1.5-\mathrm{m} \times 1.5-\mathrm{m}$ ( $5 \mathrm{ft} \times 5 \mathrm{ft}$ ) grid over the remedial action areas. Samples were collected to a depth of $5 \mathrm{~cm}$ ( 2 in.) where soil was available. Much of the area was barren sandstone or tuff following the excavation of the contaminated overburden. At points where soil was not present, the upper $5 \mathrm{~cm}$ ( $2 \mathrm{in.}$ ) of tuff was chipped from the surface to form the sample.

Samples were pre-treated prior to analysis by drying, crushing, and thoroughly blending. Pre-treated samples were analyzed by gamma scanning using a germanium detector or prepared using wet chemistry 
techniques for determination of concentrations of alpha- or beta-emitting radionuclides. By the nature of the waste streams constituting the source of the contaminants, plutonium-239 was the most prevalent radionuclide and was used as the controlling radionuclide for analysis of verification samples collected in the untreated waste outfall area. At the vehicle decontamination facility, cesium-137 and strontium-90 were the most prevalent radionuclides and were used as the controls for verification sample analysis.

For plutonium analyses, the pre-treated sample was aliquotted and the plutonium was leached from the aliquot. The plutonium recovered was electroplated on a metal counting planchet and the plutonium-238 and plutonium-239/240 activities were determined by alpha spectrographic analysis. The total efficiency of the process was determined through use of a tracer.

Determination of americium-241 utilized a similar methodology that was specific to americium rather than plutonium. Analysis of the sample for americium-24l utilized alpha spectrographic analysis.

Determination of strontium-90 concentration in the sample utilized the yttrium ingrowth technique. As with plutonium the sample was aliquotted, leached, and electroplated on a metal counting planchet prior to analysis.

Compliance with remedial action criteria listed in Table 4-1 was determined by the above analyses of soil samples and measurements of near-surface gamma radiation.

Verification was based primarily on the soil sample analyses due to the types of radiation emitted by the radionuclides of interest (alpha, beta, and low energy gamma-rays). External exposure rates were measured to complement soil sample analyses for the few gamma emitters that were present, cesium-137 and radium-226 and its daughters. 
While in situ measurements were made during all phases of the remedial action (surface gamma and surface beta-gamma measurements.) to guide excavation, they were of little or no use in determining compliance and were not included as part of this summary of the data.

\subsection{POST-REMEDIAL ACTION STATUS}

The migration route of the waterborne contamination and the 1976-77 LANL survey indicated that no contamination above criteria existed east of the ravine into which the untreated waste flowed. There is a clear line between contaminated and uncontaminated soil denoted by the east bank of the ravine. Therefore, samples for verification of the adequacy of the remedial action were collected within the area that was bounded on the east by the east bank of the ravine.

Within the untreated waste outfall area, the remedial action covered an area of approximately $100 \mathrm{~m}^{2}\left(1,000 \mathrm{ft}^{2}\right)$; therefore, data were averaged over the remedial action area to determine compliance with criteria. Post-remedial action sample data are presented in Table 5-1 and on Figure 5-1. The average concentration in soil in the remedial action area was $36 \mathrm{pCi} / \mathrm{g}$ plutonium-239. The maximum measured soil concentration was $370 \mathrm{pCi} / \mathrm{g}$ plutonium-239. A total of five samples within a small area in the ravine exceeded the criterion for plutonium-239 based on the more stringent food cultivation/ingestion pathway. In this area the average concentration of plutonium contamination was $226 \mathrm{pCi} / \mathrm{g}$. Utilizing the more appropriate resuspension/inhalation pathway, all soil sample data were less than 5 percent of the criterion $(7600 \mathrm{pCi} / \mathrm{g})$. In view of the small size of this area relative to the site as a whole and the average concentration of plutonium-239 in the entire remedial action area, it was concluded that no additional remedial action was warranted based on plutonium-239 concentrations.

Plutonium-238 concentrations over the remedial action area were insignificant at less than $2 \mathrm{pCi} / \mathrm{g}$ or less than 2 percent of the food cultivation/ingestion pathway criterion for plutonium-238 $(100 \mathrm{pCi} / \mathrm{g})$. 
TABLE 5-1

ACID CANYON POST-REMEDIAL ACTION

SOIL SAMPLE DATA

COORDINATES

\begin{tabular}{|c|c|c|c|c|c|c|}
\hline$x$ & $Y$ & $\begin{array}{c}\text { Plutonium } \\
239 \\
\end{array}$ & $\begin{array}{c}\text { Plutonium } \\
238 \\
\end{array}$ & $\begin{array}{l}\text { Americium } \\
241 \\
\end{array}$ & $\begin{array}{c}\text { Cesium } \\
137 \\
\end{array}$ & $\begin{array}{c}\text { strontium } \\
90 \\
\end{array}$ \\
\hline 40 & 35 & $\mathrm{~N} / \mathrm{A}$ & $\mathrm{N} / \mathrm{A}$ & $5.4 \pm 0.5$ & $8.5 \pm 0.9$ & $\mathrm{~N} / \mathrm{A}$ \\
\hline 60 & 30 & $N / A$ & $\mathrm{~N} / \mathrm{A}$ & $0.4 \pm 0.1$ & $1.2 \pm 0.1$ & $\mathrm{~N} / \mathrm{A}$ \\
\hline 123 & 63 & $140 \pm 10$ & $0.7 \pm 0.6$ & $\mathrm{~N} / \mathrm{A}$ & $\mathrm{N} / \mathrm{A}$ & N/A \\
\hline 125 & 60 & $200 \pm 10$ & $2 \pm 1$ & $\mathrm{~N} / \mathrm{A}$ & $N / A$ & $\mathbf{N} / \mathbf{A}$ \\
\hline 125 & 65 & $230 \pm 10$ & $1.2 \pm 0.6$ & $\mathrm{~N} / \mathrm{A}$ & $\mathrm{N} / \mathrm{A}$ & $\mathrm{N} / \mathrm{A}$ \\
\hline 125 & 70 & $1.9 \pm 0.6$ & $0.3 \pm 0.3$ & $\mathrm{~N} / \mathrm{A}$ & $\mathrm{N} / \mathrm{A}$ & $\mathbf{N} / \mathbf{A}$ \\
\hline 130 & 50 & $18 \pm 2$ & $0.2 \pm 0.3$ & $\mathrm{~N} / \mathrm{A}$ & $\mathrm{N} / \mathrm{A}$ & $\mathrm{N} / \mathrm{A}$ \\
\hline 130 & 55 & $82 \pm 3$ & $0.5 \pm 0.2$ & $\mathrm{~N} / \mathrm{A}$ & $\mathrm{N} / \mathrm{A}$ & $\mathrm{N} / \mathrm{A}$ \\
\hline 130 & 60 & $77 \pm 4$ & $0.2 \pm 0.3$ & $\mathrm{~N} / \mathrm{A}$ & $\mathrm{N} / \mathrm{A}$ & $\mathrm{N} / \mathrm{A}$ \\
\hline 130 & 65 & $190 \pm 30$ & $0.5 \pm 0.5$ & $\mathrm{~N} / \mathrm{A}$ & $\mathrm{N} / \mathrm{A}$ & $N / A$ \\
\hline 130 & 70 & $370 \pm 10$ & $1.4 \pm 0.6$ & $\mathrm{~N} / \mathrm{A}$ & $\mathrm{N} / \mathrm{A}$ & $N / A$ \\
\hline 135 & 45 & $2 \pm 1$ & $0.1 \pm 0.1$ & $\mathrm{~N} / \mathrm{A}$ & $\mathrm{N} / \mathrm{A}$ & $\mathrm{N} / \mathrm{A}$ \\
\hline 135 & 50 & $1.1 \pm 2$ & $0.1+0.3$ & $\mathrm{~N} / \mathrm{A}$ & $\mathrm{N} / \mathrm{A}$ & $\mathrm{N} / \mathrm{A}$ \\
\hline 135 & 5.5 & $31 \pm 3$ & $0.2 \pm 0.3$ & $\mathrm{~N} / \mathrm{A}$ & $\mathrm{N} / \mathrm{A}$ & $\mathrm{N} / \mathrm{A}$ \\
\hline 135 & 60 & $7 \pm 1$ & $0.2 \pm 0.4$ & $\mathrm{~N} / \mathrm{A}$ & $\mathrm{N} / \mathrm{A}$ & $\mathrm{N} / \mathrm{A}$ \\
\hline 135 & 65 & $2 \pm 1$ & $0.1 \pm 0.2$ & $\mathrm{~N} / \mathrm{A}$ & $\mathrm{N} / \mathrm{A}$ & $\mathrm{N} / \mathrm{A}$ \\
\hline 135 & 70 & $4 \pm 1$ & $0.0 \pm 0.1$ & $\mathrm{~N} / \mathrm{A}$ & $\mathrm{N} / \mathrm{A}$ & $\mathrm{N} / \mathrm{A}$ \\
\hline 140 & 45 & $2 \pm 1$ & $0.0 \pm 0.3$ & $\mathrm{~N} / \mathrm{A}$ & $\mathrm{N} / \mathrm{A}$ & $N / A$ \\
\hline 140 & 50 & $6 \pm 1$ & $0.1 \pm 0.2$ & $\mathrm{~N} / \mathrm{A}$ & $\mathrm{N} / \mathrm{A}$ & $\mathrm{N} / \mathrm{A}$ \\
\hline 140 & 55 & $21 \pm 3$ & $0.2 \pm 0.3$ & $\mathrm{~N} / \mathrm{A}$ & $\mathrm{N} / \mathrm{A}$ & $\mathbf{N} / \mathbf{A}$ \\
\hline
\end{tabular}

$\mathrm{pCi} / \mathrm{g}$

page 1 of 3 
TABLE 5-1

(continued)

COORDINATES

\begin{tabular}{|c|c|c|c|c|c|c|}
\hline $\mathrm{X}$ & $\mathrm{X}$ & $\begin{array}{l}\text { Plutonium } \\
239 \\
\end{array}$ & $\begin{array}{c}\text { Plutonium } \\
238 \\
\end{array}$ & $\begin{array}{l}\text { Americium } \\
241 \\
\end{array}$ & $\begin{array}{c}\text { Cesium } \\
137 \\
\end{array}$ & $\begin{array}{l}\text { strontium } \\
90 \\
\end{array}$ \\
\hline 140 & 60 & $17 \pm 2$ & $0.4 \pm 0.3$ & N/A & $\mathrm{N} / \mathrm{A}$ & $\mathrm{N} / \mathrm{A}$ \\
\hline 140 & 65 & $0.4 \pm 0.3$ & $0.1 \pm 0.1$ & $\mathrm{~N} / \mathrm{A}$ & $\mathrm{N} / \mathrm{A}$ & $\mathrm{N} / \mathrm{A}$ \\
\hline 140 & 70 & $0.3 \pm 0.3$ & $0.0 \pm 0.1$ & $\mathrm{~N} / \mathrm{A}$ & $\mathrm{N} / \mathrm{A}$ & N/A \\
\hline 145 & 50 & $11 \pm 1$ & $<0.1$ & $N / A$ & $\mathbf{N} / \mathbf{A}$ & $\mathrm{N} / \mathrm{A}$ \\
\hline 145 & 55 & $6 \pm 1$ & $0.5 \pm 0.5$ & $N / A$ & $N / A$ & N/A \\
\hline 145 & 60 & $7 \pm 1$ & $0.1 \pm 0.1$ & $\mathrm{~N} / \mathrm{A}$ & $N / A$ & $\mathrm{~N} / \mathrm{A}$ \\
\hline 145 & 65 & $5 \pm 1$ & $0.4 \pm 0.4$ & $N / A$ & $N / A$ & $N / A$ \\
\hline 145 & 70 & $2.4 \pm 0.4$ & $0.1 \pm 0.1$ & $\mathrm{~N} / \mathrm{A}$ & $N / A$ & $\mathrm{~N} / \mathrm{A}$ \\
\hline 150 & 45 & $40 \pm 2$ & $0.8 \pm 0.3$ & $<1$ & $<1$ & $<0.9$ \\
\hline 150 & 50 & $17 \pm 2$ & $<0.2$ & $\mathrm{~N} / \mathrm{A}$ & $\mathrm{N} / \mathrm{A}$ & $\mathrm{N} / \mathrm{A}$ \\
\hline 150 & 55 & $20 \pm 3$ & $0.6 \pm 0.5$ & $\mathrm{~N} / \mathrm{A}$ & $N / A$ & $\mathrm{~N} / \mathrm{A}$ \\
\hline 150 & 60 & $5 \pm 1$ & $0.0 \pm 0.1$ & $\mathrm{~N} / \mathrm{A}$ & $\mathrm{N} / \mathrm{A}$ & $\mathrm{N} / \mathrm{A}$ \\
\hline 150 & 65 & $3 \pm 1$ & $0.2 \pm 0.3$ & $\mathrm{~N} / \mathrm{A}$ & $\mathrm{N} / \mathrm{A}$ & $\mathrm{N} / \mathrm{A}$ \\
\hline 150 & 70 & $0.5 \pm 0.2$ & $0.0 \pm 0.1$ & $\mathrm{~N} / \mathrm{A}$ & $\mathrm{N} / \mathrm{A}$ & $\mathrm{N} / \mathrm{A}$ \\
\hline 150 & 75 & $16 \pm 1.5$ & $0.07 \pm 0.15$ & $<1$ & $2.3 \pm 0.2$ & $1.2 \pm 0.5$ \\
\hline 150 & 0 & $0.9 \pm 0.3$ & $0.06 \pm 0.08$ & $<1$ & $<1$ & $<1$ \\
\hline 150 & 15 & $0.6 \pm 0.3$ & $0.003 \pm 0.009$ & $<1$ & $0.1 \pm 0.1$ & 0.6 \\
\hline 150 & 30 & $2.2+0.5$ & $0.4 \pm 0.2$ & $0.3 \pm 0.3$ & $0.6 \pm 0.1$ & $<0.6$ \\
\hline 155 & 50 & $24 \pm 1$ & $0.1 \pm 0.1$ & $N / A$ & $\mathrm{~N} / \mathrm{A}$ & $\mathrm{N} / \mathrm{A}$ \\
\hline 155 & 55 & $11 \pm 1$ & $0.1 \pm 0.1$ & $\mathrm{~N} / \mathrm{A}$ & $\mathrm{N} / \mathrm{A}$ & $\mathrm{N} / \mathrm{A}$ \\
\hline 155 & 60 & $0.5 \pm 0.2$ & $0.0 \pm 0.1$ & $N / A$ & $\mathrm{~N} / \mathrm{A}$ & N/A \\
\hline 155 & 65 & $5 \pm 1$ & $0.1 \pm 0.2$ & $N / A$ & $\mathrm{~N} / \mathrm{A}$ & $N / A$ \\
\hline
\end{tabular}

$\mathrm{pCi} / \mathrm{q}$

\section{COORDINATES}

\section{(1)}

page 2 of 3 
TABLE 5-1

(continued)

COORDINATES

$\mathrm{iCi} / \mathrm{y}$

\begin{tabular}{|c|c|c|c|c|c|c|}
\hline$X$ & $Y$ & $\begin{array}{c}\text { Plutonium } \\
239 \\
\end{array}$ & $\begin{array}{c}\text { Plutonium } \\
238 \\
\end{array}$ & $\begin{array}{l}\text { Americium } \\
241 \\
\end{array}$ & $\begin{array}{c}\text { Cesium } \\
137 \\
\end{array}$ & $\begin{array}{l}\text { strontium } \\
90 \\
\end{array}$ \\
\hline 165 & 0 & $0.09 \pm 0.13$ & $0.05 \pm 0.09$ & $<1$ & $0.1 \pm 0.1$ & $<0.7$ \\
\hline 165 & 15 & $2 \pm 0.5$ & $0.08 \pm 0.13$ & $<1$ & $0.3 \pm 0.1$ & $<0.9$ \\
\hline 165 & 30 & $6 \pm 0.8$ & $0.4 \pm 0.2$ & $<1$ & $<1$ & $<0.6$ \\
\hline 165 & 45 & $2.5 \pm 0.5$ & $0.3 \pm 0.2$ & $0.3 \pm 0.1$ & $0.3 \pm 0.1$ & $<0.6$ \\
\hline 180 & 50 & $0.3 \pm 0.2$ & $0.2 \pm 0.2$ & $<1$ & $<1$ & $<0.7$ \\
\hline
\end{tabular}

N/A Not analyzed 


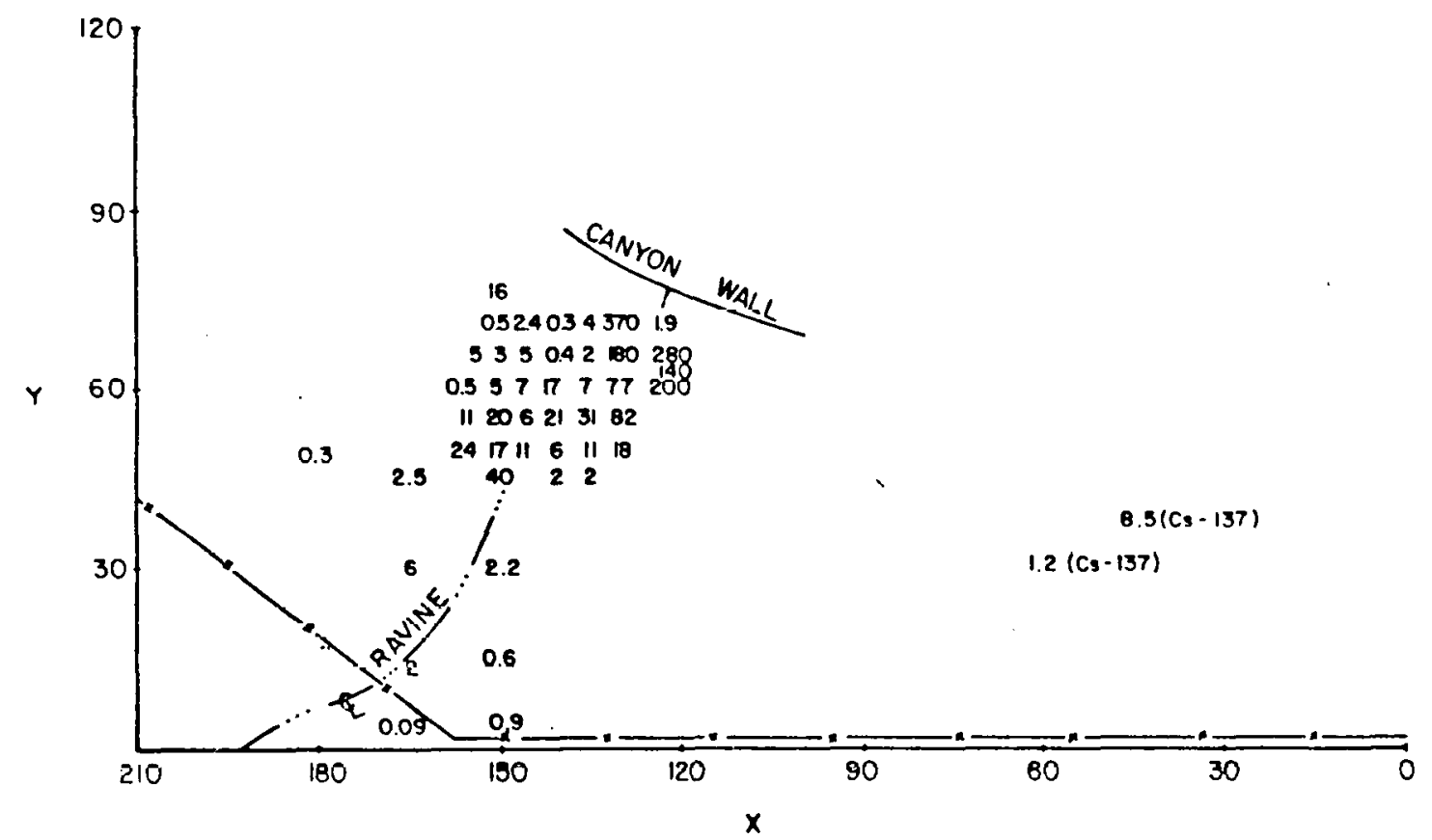

FIGURE 5-1 POST-REMEDIAL ACTION PLUTONIUM-239 CONCENTRATION IN SOIL IN pCi/g (CESIUM-137 INCLUDED TO INDICATE MIXED FISSION PRODUCT CONTAMINATION) 
In addition to plutonium analyses, samples collected after the excavation initiated on August 4, 1982 were analyzed for americium-241, cesium-137, and strontium-90. Concentrations of these radionuclides were less than one percent of the applicable guide. Therefore, soil samples collected after hot spot excavation were analyzed only for plutonium-238 and -239. Those samples that were from portions of the site not included in the hot spot cleanup were included for verification purposes. Therefore, 11 soil samples in Table 5-1 include analyses for americium-241, cesium-137, and strontium-90.

Post-remedial action external exposure rates near the untreated waste outfall are presented in Table 5-2. The average exposure rate was $17 \mathrm{uR} / \mathrm{h}$ compared to the Los Alamos area average, 9.4 to $17.4 \mathrm{uR} / \mathrm{h}$.

Within the former vehicle decontamination facility area, verification of the adequacy of the remedial action was based on soil sample analysis for the primary contaminants, cesium-137 and strontium-90, and external exposure rates. Based on two soil samples taken in this area the concentration of cesium-137 after remedial action was less than 10 percent of the criterion.

While the primary contaminants were cesium-137 and strontium-90, spotty plutonium-239 contamination also existed in the area as evidenced by one of ten pre-remedial action samples. However, based on these ten samples, the maximum permissable area averaged concentration of plutonium-239 (100 pci/g) was not exceeded. The requirement to perform remedial action in the vehicle decontamination area was based on the concentrations of cesium-137 and strontium-90 in the soil. Therefore, no analysis for plutonium-239 was performed on post-remedial action samples collected from this area.

The external exposure rate near the former vehicle decontamination facility was $23 \mu \mathrm{R} / \mathrm{h}$. 
TABLE 5-2

ACID CANYON POST-REMEDIAL ACTION

EXTERNAL EXPOSURE RATES (INCLUDING BACKGROUND)

COORDINATES

EXPOSURE RATE $(\mu R / h)$

$\underline{\mathrm{X}} \quad \underline{\mathrm{Y}}$

Former Vehicle Decontamination Facility

$\begin{array}{lll}35 & 30 & 32 \\ 40 & 30 & 22 \\ 45 & 40 & 22 \\ 45 & 45 & 19 \\ 50 & 45 & 21\end{array}$

AVERAGE 23

Untreated Waste Outfall

$135 \quad 60 \quad 10$

$140 \quad 50 \quad 19$

$140 \quad 55 \quad 19$

$\begin{array}{lll}140 & 60 & 17\end{array}$

$145 \quad 45 \quad 17$

$150 \quad 0 \quad 14$

$150 \quad 5 \quad 16$

$150 \quad 10 \quad 17$

$150 \quad 15 \quad 17$

$150 \quad 20 \quad 17$

$150 \quad 25 \quad 17$

$150 \quad 30 \quad 18$

$\begin{array}{lll}150 & 35 & 18\end{array}$

$\begin{array}{lll}150 & 40 & 17\end{array}$

$\begin{array}{lll}150 & 45 & 17\end{array}$

$\begin{array}{lll}150 & 50 & 17\end{array}$

$150 \quad 55 \quad 17$

$\begin{array}{lll}150 & 60 & 17\end{array}$

page 1 of 3 
TABLE 5-2

(continued)

COORDINATES

$\underline{X} \underline{Y} \quad \underline{E X P O S U R E} \operatorname{RATE}(\mu R / \mathrm{h})$

Former Vehicle Decontamination Facility

$150 \quad 65$

17

$150 \quad 70$

18

$150 \quad 75$

17

1550

15

$155 \quad 5$

15

$155 \quad 10$

17

$155 \quad 15$

17

15520

17

$155 \quad 25$

18

15530

17

$155 \quad 35$

17

15540

17

$155 \quad 45$

17

$155 \quad 50$

18

15560

17

$160 \quad 0$

15

$160 \quad 5$

15

$160 \quad 10$

15

$160 \quad 15$

16

$160 \quad 20$

16

$160 \quad 25$

18

$160 \quad 30$

17

$160-35$

17

$160 \quad 40$

16

$160 \quad 45$

17

$160 \quad 50$

18

$160 \quad 55$

18

$160 \quad 60$

17

page 2 of 3 
TABLE 5-2

(continued)

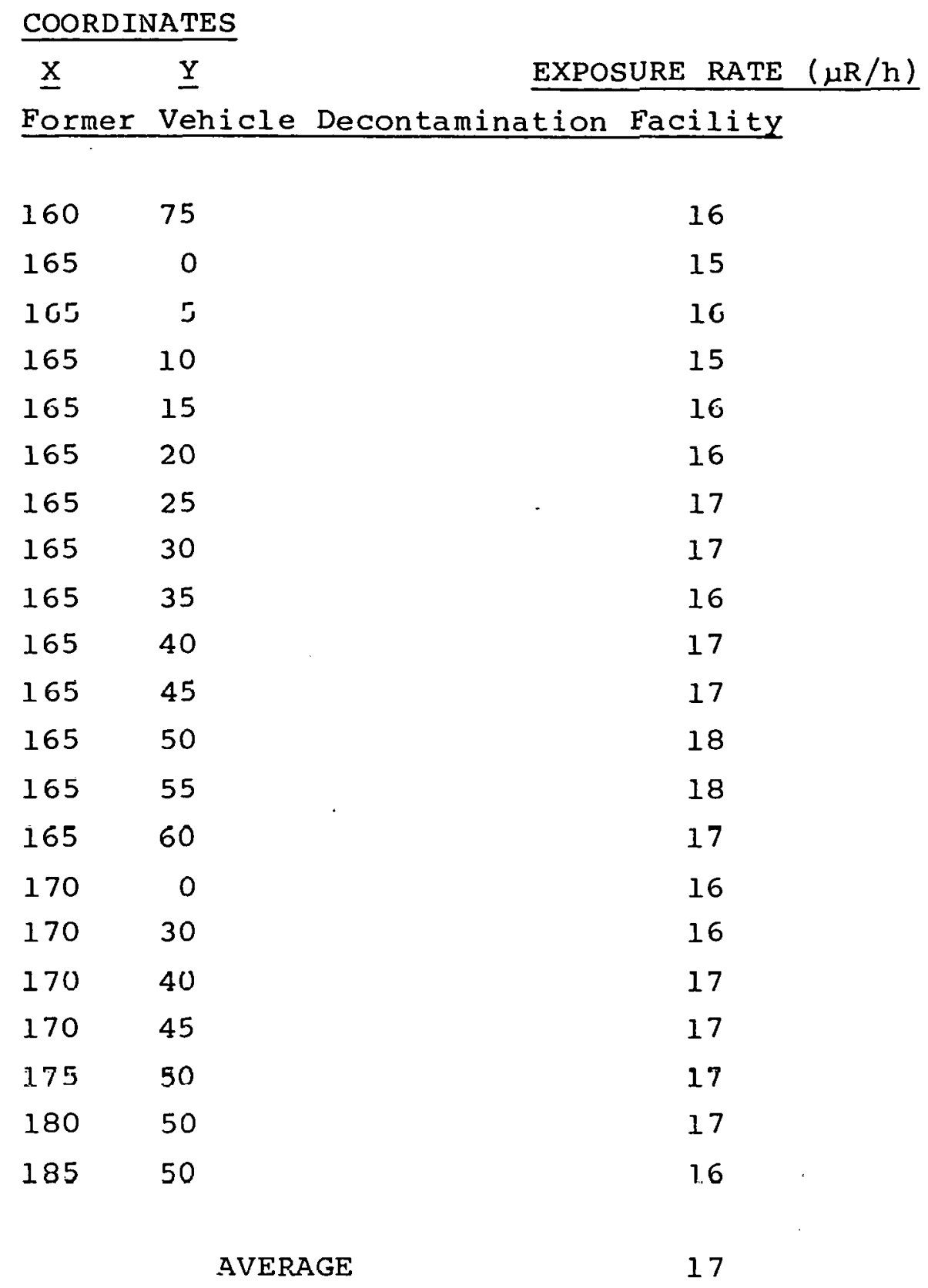

Background exposure rates in the Los Alamos area range from 9.4 to $17.4 \mu \mathrm{R} / \mathrm{h}$.

page 3 of 3 
Based on the above analyses and measurements, both the untreated waste outfall and former vehicle decontamination facility were in compliance with the remedial action criteria cited in Table 4-1. Compliance was confirmed by the LANL Environmental Surveillance Group (Reference 13).

\subsection{ANALYSIS OF REMAINING CONTAMINATION BEYOND THE TWO REMEDIAL ACTION AREAS}

In the first $100 \mathrm{~m}$ (30 ft) of the active channel below the $\mathrm{rim}$ of Acid Canyon the estimated concentration of plutonium-239 is $154 \mathrm{pCi} / \mathrm{g}$. The maximum concentration measured by the LANL survey was $629 \mathrm{pCi} / \mathrm{g}$. Over the $750 \mathrm{~m}(2300 \mathrm{ft})$ length of Acid Canyon the average concentration of plutonium-239 in the active channel is $30.6 \mathrm{pCi} / \mathrm{g}$, while in the banks of the active channel it is $110 \mathrm{pCi} / \mathrm{g}$ (Reference 1 ).

Based on the rough terrain in the canyon and the minimal number of plausible pathways to man there, it was determined that remedial action in the channel was not required. Plausible pathways include resuspension/inhalation and erosion into Lower Pueblo Canyon where gardening is possible. The remedial action criterion for resuspension/inhalation is $7600 \mathrm{pCi} / \mathrm{g}$, which is significantly higher than the contamination levels in Acid Canyon.

While the food/gardening pathway in Acid Canyon was eliminated from consideration, material now in Acid Canyon will eventually erode into Lower Pueblo Canyon. Based on data collected by LANL, the dilution factor between Acid and Lower Pueblo Canyons is six. Consequently, material from Acid Canyon, once diluted and dispersed, will not significantly alter the concentrations of plutonium-239 now in Lower Pueblo Canyon. The maximum concentration of plutonium-239 expected in Lower Pueblo Canyon would be approximately $20 \mathrm{pCi} / \mathrm{g}$ or 20 percent of the cleanup criteria based on the sum of all pathways. 
Based on extrapolation of calculations performed in the 1976-77 LANL radiological survey, the home gardener in Lower Pueblo Canyon would be expected to receive an annual dose of $0.3 \mathrm{mrem}$ to bone and $2 \mathrm{mrem}$ to lung. These doses are a small fraction of the 1500 mrem limit for exposure to the general public specified in DOE Order 5480.1A (Reference 14) and represent an insignificant health risk. 


\section{$6.0 \cos T$}

The total cost of the remedial action at Acid/Pueblo Canyon was $\$ 1,037,800$. Extensive radiological characterization and subsequent engineering analysis were the major cost contributors. In-depth characterization was essential to ensure that all contaminants were located and identified. In addition, LANL performed extensive modeling of the migration of contaminants from Acid Canyon to Lower Pueblo Canyon to determine whether remedial action was required in the channel of Acid Canyon. This large data base was then assessed in detail to establish the most cost-effective remedial action option. After methodical review of several alternatives, each of which involved a significant amount of preliminary engineering effort, excavation of the contaminated material and disposal at a designated disposal site was selected. This engineering effort resulted in a minimum-cost remedial action solution for the Acid/Pueblo Canyon site which complied fully with all established criteria.

The construction costs were allocated in FY 1982. With the completion of the remedial action, these costs were reduced and in FY 1983 unexpended funds were returned to FuSRAP. The \$19,000 cost for disposal of the $390 \mathrm{yd}^{3}$ at the LANL site is quite reasonable (approximately $\$ 1.80 / \mathrm{ft}^{3}$ ).

The BNI project costs for FY 1981 were directly influenced by the DOE-ORO policy to apportion all first-year FUSRAP program start-up costs among FUSRAP sites active during that fiscal year. Since BNI assumed the role of the PMC for FUSRAP in April 1981, its start-up costs were applied to eight active sites, including Acid/Pueblo canyon. The actual cost of FY 1981 activities attributable to each site was not firmly defined because manhour accounting procedures were not fully operational. Consequently each site was allocated an approximately equal share of start-up costs rather than a proportionate one hased on actual manhours expended. 
The Acid/Pueblo Canyon Cost Summary (Table 6-1) provides a breakdown of cost by fiscal year and discipline. The construction cost appears low when compared with engineering/characterization, radiological, and management costs. Comparison of these costs based on the volume of contaminated material removed is not a valid indication of program effectiveness for two reasons. First, the construction cost was minimized by effective front-end engineering/characterization, which in turn minimized the amount of excavation required. A more appropriate comparison would include radiological/safety and licensing with construction since the former is essential to verification of the remedial action. Second, the costs associated with engineering, radiological characterization, safety, environmental assessment, documentation, and management are less directly related to the volume of contaminated material handled whereas construction cost is a mure difect funcliun uf lis volume. 
TABLE 6-1

ACID/PUEBLO CANYON

COST SUMMARY

ENGINEERING / CHARACTERIZATION

$\underline{1981} \underline{1982} \underline{1983} \underline{\text { Total }}$

BNI

FBDU

LANL

NLO
$18,000 \quad 26,600$

32,200

$59,400 \quad 144,000$

53,000
6,600

51,200

32,200

203,400

53,000

ENVIRONMENTAL ANALYSIS

ANL

43,000
$74,600 \quad 181,000$

$.43,000$

LANL

255,600

RADIOLOGICAL/SAFETY\& LICENSING

BNI

9.000

4,700

8,900

22,600

EI.C

32,600

13,800

46,400

LANL-DISPOSAL

6,000

6,000

CONSTRUCTION

$\mathrm{BNI}$

ZIA

PLS

LAN L_-DI S POSAL

$\begin{array}{rrr}9,200 & {[900]} & 8,300 \\ 45,000 & {[25,700]} & 19,300 \\ 1,400 & {[300]} & 1,100 \\ & 19,000 & 19,000\end{array}$

MANAGEMENT \& SUPPORT

$\mathrm{BNI}$

89,400

2,100

$91,500^{\circ}$

APPORTIONED START-UP COST

$185,200 *$

185,200

TOTAL

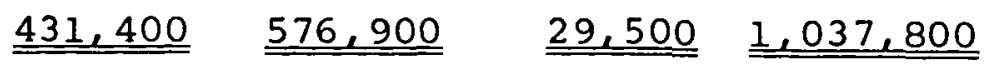

*Includes 1981 BNI Management and Support Costs. 


\section{REFERENCES}

1. Los Alamos National Laboratory. Radiological survey of the Site of the Former Radioactive Liquid Waste Treatment Plant $(T A-45)$ and the Effluent Receiving Areas of Acid, Pueblo, and Los Alamos Canyons, Los Alamos, New Mexico, DOE/EV-0005-30, Los Alamos, NM, May 1981.

2. Bechtel National, Inc. Preliminary Engineering Evaluation of Remedial Action Alternatives, Acid/Pueblo Canyon, Los Alamos, New Mexico, 10-05-01B-001, Oak Ridge, TN, September 1982 .

3.. Los Alamos National Laboratory. Environmental Analysis of Acid/Middle Pueblo Lanyon, LUs Alamus, New Mexico, LA-9409-MS, Los Alamos, NM, August 1982.

4. Letter, L. Soholt to K. Harer et al. "Revised ADM for Acid/ Midale Pueblo Canyon Remedial Action," April 16, 1982.

5. U.S. Code of Federal Regulations. 40 CFR 192 "Environmental Protection standaras for Usduium and Thorium Mill Tailings at. Licensed Commercial Processing Sites," Waślington, DC, Jalluāly 1983.

6. Los Alamos Scientific Laboratory. Interim Soil Limits for D\&D Projects, LA-UR-79-1865-Rev, Los Alamos, NM, September 1979 :

7. Los Alamos Scientific Laboratory. A Preliminary Study of Radium-Contaminated Soils, LA-7391-MS, Los Alamos, NM, October 1978.

8. Letter, E. L. Keller to R. L. Rudolph. "Criteria for Remedial Action at Acid/Pueblo and Bayo Canyons; Réquest for Cost/Benefit Analyses of Remedial Action Options at the 'Canyons," March 17, 1982. 
9. U.S. Department of Energy. Energy Systems Acquisition Project Plan (ESAPP), Formerly Utilized MED/AEC Sites Remedial Action Program (FUSRAP), Oak Ridge, TN, December 1983.

10. Bechtel National, Inc. Health and Safety Program, Oak Ridge, TN, March 1982 (revised June 1983).

11. Bechtel National, Inc. Radiological Protection Program, Oak Ridge, TN, May 1982 (revised June 1983).

12. Bechtel National, Inc. Quality Assurance Manual, Oak Ridge, TN, April 1982, (revised March 1983).

13. Los Alamos National Laboratory. Radiological Survey Following Decontamination Activities Near the TA-45 Site, LA-9831-MS, Los Alamos, NM, July 1983.

14. U.S. Department of Energy. Order 5480.1A, "Environmental Protection, Safety and Health Protection Program for DOE Operations," Washington, DC, June 1982. 
